\title{
EDITORIAL
}

\section{JOSÉ ANTÔNIO GOMES DE SOUZA, O MÉDICO, O AMIGO, O GUERREIRO.}

\author{
Roberto Frota Pessoa
}

Tomado por intenso amor, desfez o noivado e após três meses estava casado com Nina, que conheceu em Serra do Navio, Amapá. Ela vinda do Rio de Janeiro para visitar seu pai, e ele lá já trabalhando, recém-formado, como médico da ICOME - Indústria e Comércio de Minérios. Deste amor, que trouxe consigo por toda a vida, nasceram Fabiano, Fernando e Mariana.

No Amapá era o cirurgião geral que de tudo fazia, dos partos à ortopedia. Seu destino o levou a Brasília onde trabalhou na Universidade com o Dr. Hélio Barbosa. Por onde passou deixou a marca da seriedade, da competência e de fazer amigos. Não foram diferentes os sete anos que trabalhou na Hidroelétrica de Itaipu, em Foz de Iguaçu, onde venceu o desafio de montar um Serviço de Cirurgia Geral. É desta época a lembrança que tenho do José Antônio, apresentando trabalho científico no Congresso Brasileiro de Cirurgiões, em São Paulo. Material estudado com todo cuidado e zelo profissional em Foz do Iguaçu.

Em 1983 voltou ao Rio de Janeiro e ao Hospital Miguel Couto, que havia sido o local de trabalho e aprendizado após sua formatura pela Faculdade de Ciência Médicas do Rio de Janeiro, em 1968. Logo se destacou pela competência cirúrgica, dedicação e conhecimentos médicos.

Conhecidos há muitos anos, passamos a trabalhar juntos, a compartilhar as mesmas dificuldades, a lutar ombro a ombro, tornamo-nos amigos. E foi assim, de perto, que pude conhecer o guerreiro.

Sua saúde que o obrigou durante 13 anos a se submeter três vezes por semana a quatro horas de hemodiálise, os infartos do miocárdio, o primeiro deles aos 38 anos ainda em Foz do Iguaçu, a pancreatite secundária à colelitíase que o levou à mesa de cirurgia, nada o afastou do que considerava serem suas obrigações para com a família e com seus pacientes. Nunca ouvi uma palavra de revolta, nunca a doença o fez esmorecer nem foi motivo para deixar de fazer tudo que um grande cirurgião se obriga a fazer. A busca de atualização científica no Brasil e no exterior, o ensino, a preocupação e o cuidado com os pacientes, a dedicação a sua entidade de classe, o Colégio Brasileiro de Cirurgiões.

A possibilidade do transplante renal, sabedor que em uso de imunossupressores poderia ter que evitar pacientes infectados em hospitais, nunca o encantou.

A cirurgia cardíaca que acabou sendo inevitável foi mais um ataque ao guerreiro, que mesmo combalido recuperouse e voltou a operar e trabalhar como sempre, esmerando-se para que a revista e o boletim do Colégio Brasileiro de Cirurgiões, mais uma de suas responsabilidades, pudessem estar prontas com antecedência e alto nível científico.

Foi neste cenário, 15 minutos após ligar para Nina, seu grande amor, avisando estar bem e pedindo para que fosse pegá-lo dali a pouco na hemodiálise, que após forte dor pré-cordial o guerreiro recebeu o golpe final.

Assim, deixou de viajar no dia seguinte para Fortaleza para participar de um congresso médico. Assim, deixou de operar seus doentes. Assim, deixou de dirigir as publicações do Colégio Brasileiro de Cirurgiões. Assim, deixou a Nina, o Fabiano, o Fernando e a Mariana. Assim, rapidamente, como para compensar o tanto que deve no íntimo ter sofrido em tantos anos de luta, deixou seus amigos.

OBRIGADO, JOSÉ ANTÔNIO GOMES DE SOUZA, POR TER NOS ENSINADO QUE VIVER VALE A PENA!

ROBERTO SAAD JUNIOR. 